\title{
Simulation of washability and liberation information from photographs
}

H.C.Dorland, University of Johannesburg (CIMERA), Research Associate, PhD, PO Box 524, Auckland Park, 2006, South Africa, +27115594728, hermand@UJ.ac.za

Q.P. Campbell, North-West University, Associate Professor, PhD, Private Bag X6001, Potchefstroom, 2531, South Africa, +27182991993, quentin.campbell@nwu.ac.za

M. Le Roux North-West University, Associate Professor, PhD, Private Bag X6001, Potchefstroom, 2531, South Africa, +27182991990, marco.leroux@nwu.ac.za

K. McMillan, Anglo American, Coal Processing Technical Specialist, HND Extractive Metallurgy, HNC Advanced Coal Preparation, Pr Tech Eng, Private Bag X9 Leraatsfontein Witbank 1038 South Africa, +27136915291/+27832930960, kevin.mcmillan@angloamerican.com

M.I. Dorland, The Workshop et al, Independent Consultant, BSc (Honours), PO Box 44249, Linden, 2104, South Africa, +27823825281,maria.dorland@theworkshop-et-al.co.za

P. Erasmus, EMT Consulting, Principal Technologist, NHD Water Care, ND Analytical Chemistry, MDP, PO Box 13717, Leraatsfontein, Witbank, 1038, South Africa, +27828981238,

Pieter@emtconsult.co.za

N. Wagner, University of Johannesburg, Associate Professor, PhD, PO Box 524, Auckland Park, 2006, South Africa, +27115594719, nwagner@uj.ac.za

\begin{abstract}
Imagine that a sample of coal could be crushed unlimited times to the same or different top size; a different washability would be obtained for each crushing experiment. Depending on the size and distribution of the raw coal components (say vitrinite, inertinite, and mudstone), better yields for a low ash product are obtained as a top size is approached that is the same or smaller than the components that need to be liberated. As the top size approaches the size of the components that need to be liberated (or smaller), near density material will start decreasing and the density differences between the components that need to be separated will become larger, because mostly "clean" single component particles are produced, that have widely different densities. As the virtual particle size decreases, the concentration or yield of the low ash product increases to a maximum, as the macerals are completely liberated from mineral matter
\end{abstract}

In this paper a method is proposed to predict washability characteristics by simulating how coal will behave when crushed to different top sizes and with different virtual particle size distributions, from photographs.

\section{Key Words}

Coal, crushing, washability, raw coal components, near density material, simulation, macerals.

\section{Introduction}

There are two types of factors that influence coal washability: 1) the inherent characteristics of the coal that cannot be controlled, and 2) the factors that can be controlled.

The following inherent coal characteristics influence washability (McMillan et al., 2015): 
- Composition

- Component size

- Inherent fracture patterns

The following characteristics are induced, and could be controlled (McMillan et al., 2015):

- Blasting

- Type of crusher used

- Design of the crusher

- Top size of the crush

- Impact force of the crush

Even though some control may be exerted over how particles break, particle breakage essentially remains random. It is not possible to know exactly what type of particles will be produced when coal is crushed, and therefore the type of washability that may result. However, by simulating washabilties that may develop at different top sizes and different particle size distributions, the washability behaviour of coal may become more predictable.

\section{Methodology}

The following steps were performed to simulate washabilities from photographs (Dorland et al., 2015):

- Photograph the core or ROM coal at close range

- Map out the components of the coal to scale on the photographs

- Create a base grid over the map of the coal at a grid cell size of $0.5 \mathrm{~mm} \times 0.5 \mathrm{~mm}$. The grid cell size must be small enough that most of the grid cells only consist of a single component.

- Estimate the areas of components in the base grid cells

- Assign estimated densities and ash to the different mapped components

- Calculate density and ash for each drawn block

- Import grid, density and ash data into geological resource estimation software

- Create a model based on the imported data in the geological resource estimation software

- Estimate density and ash for different block sizes using geological resource estimation software

- Calculate the washability tables per block size from the different block sizes

\section{Case Study}

A sample of coal from the Limpopo Coalfield, South Africa (Figure 1), was analysed by the above methodology to determine the effect of different particle size distribution on yield (Dorland et al., 2015). This Medium Rank C bituminous coal is known to be rich in vitrinite, with mineral inclusions, in agreement with the visual inspection. The mudstone is finely disseminated between the vitrinite (shiny component). The size of the vitrinite and mudstone areas vary between approximately $1 \mathrm{~mm}$ and $3 \mathrm{~mm}$.

This sample of coal was visually mapped (Figure 2). An area was chosen from the mapped out area and a grid was placed over it. The selected smallest block size was $0.5 \mathrm{~mm}$ by $0.5 \mathrm{~mm}$ in the example. At this size, most of the blocks are either clean vitrinite or clean mudstone, with 22400 blocks in the selected grid area. 


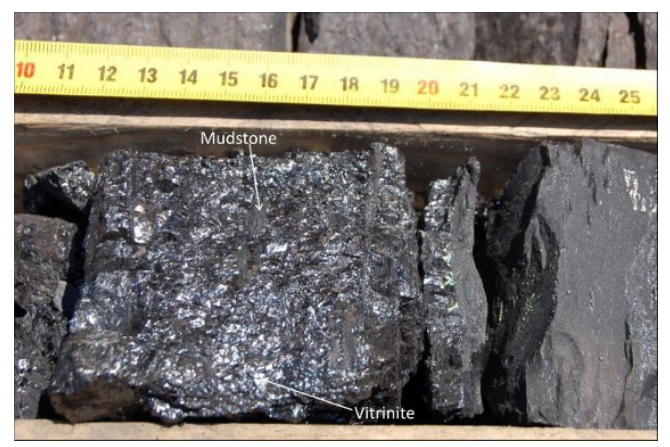

Figure 1. Limpopo Coalfield coal sample used in the case study.

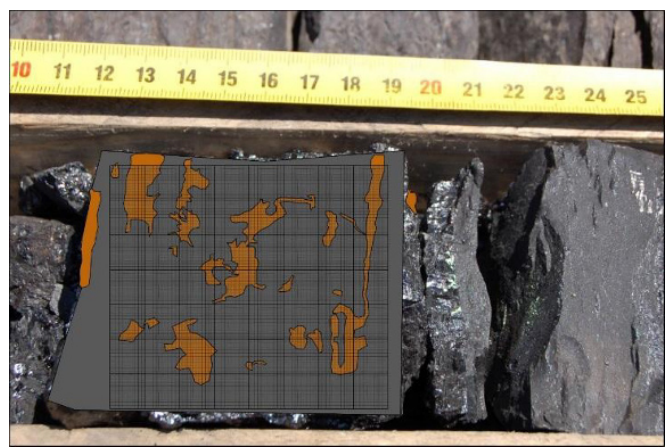

Figure 2. Map of the coal used for the case study. Grey areas are vitrinite and brown areas are mudstone. The large grid blocks are $10 \mathrm{~mm}$ by $10 \mathrm{~mm}$ and the small blocks are $0.5 \mathrm{~mm}$ by $0.5 \mathrm{~mm}$.

All the $0.5 \mathrm{~mm}$ by $0.5 \mathrm{~mm}$ blocks were named and then the compositions of all of the block areas were visually estimated by enlarging the blocks in a graphics software package. The results of the block area estimation exercise were imported into a geological resource estimation software package to create a geological model using the estimated volumes.

It was assumed that mudstone and vitrinite volumes remained the same through the sample as at the sample surface. Using this assumption, volumes for vitrinite and mudstone were determined for the following block sizes using the geological software model:

- $0.5 \mathrm{~mm}$ by $0.5 \mathrm{~mm}$ by $0.5 \mathrm{~mm}$

- $1 \mathrm{~mm}$ by $1 \mathrm{~mm}$ by $1 \mathrm{~mm}$

- $3 \mathrm{~mm}$ by $3 \mathrm{~mm}$ by $3 \mathrm{~mm}$

- $5 \mathrm{~mm}$ by $5 \mathrm{~mm}$ by $5 \mathrm{~mm}$

- $10 \mathrm{~mm}$ by $10 \mathrm{~mm}$ by $10 \mathrm{~mm}$

- $25 \mathrm{~mm}$ by $25 \mathrm{~mm}$ by $25 \mathrm{~mm}$

The volumes of vitrinite and mudstone in the blocks for the different block sizes were then imported into Excel. In Excel, calculations were then performed to estimate relative density and ash \% for each 
block. Densities of approximately RD1.35 for vitrinite and RD1.45 for inertinite were determined for South African medium rank bituminous coals by gradient centrifugation experiments (Crelling, unknown). The most abundant minerals in South African coals are quartz (RD2.65), kaolinite (RD \pm 2.16-2.68) and dolomite ( $\pm 2.84-2.86)$ (Matjie and Van Alphen, 2008; Van Dyk et al., 2009; Bunt et al., 2011, Everson et al., 2013). Hence, the following assumptions were used for the base case relative density (RD) and ash scenario for the blocks in question (Table 1):

Table 1. Assumptions used in base case washability simulations

\begin{tabular}{|l|l|l|}
\hline Component & Relative density $\left.\mathbf{( g / \mathbf { c m } ^ { 3 }}\right)$ & Ash (wt \%) \\
\hline Vitrinite & 1.35 & 4 \\
\hline Mudstone & 2.54 & 98 \\
\hline
\end{tabular}

Abbreviation :wt \% -weight percent, $\mathrm{g} / \mathrm{cm}^{3}$ - grams per cubic centimetre

After the relative densities and ash for all the blocks were calculated, the blocks in each size fraction were grouped into the following relative densities:

[0-1.35); [1.35-1.40); [1.40-1.45); [1.45-1.50); [1.50-1.55); [1.55-1.60); [1.60-1.70); [1.70-1.80); [1.80-1.90); [1.90-2.10); [2.10-2.20); [2.20-2.30); [2.30-2.40); [2.40-2.50); [2.50-2.60].

Although density classes were determined as above, density information is available for all the estimated virtual particles. Therefore, using this process, more density classes may be used to gain a better understanding of the washability characteristics of a simulation. Weight averaging was then performed to calculate yield and ash for each density class for all the block sizes.

\section{Results}

The obtained simulated washabilities for different sizes are presented in Figure 3.

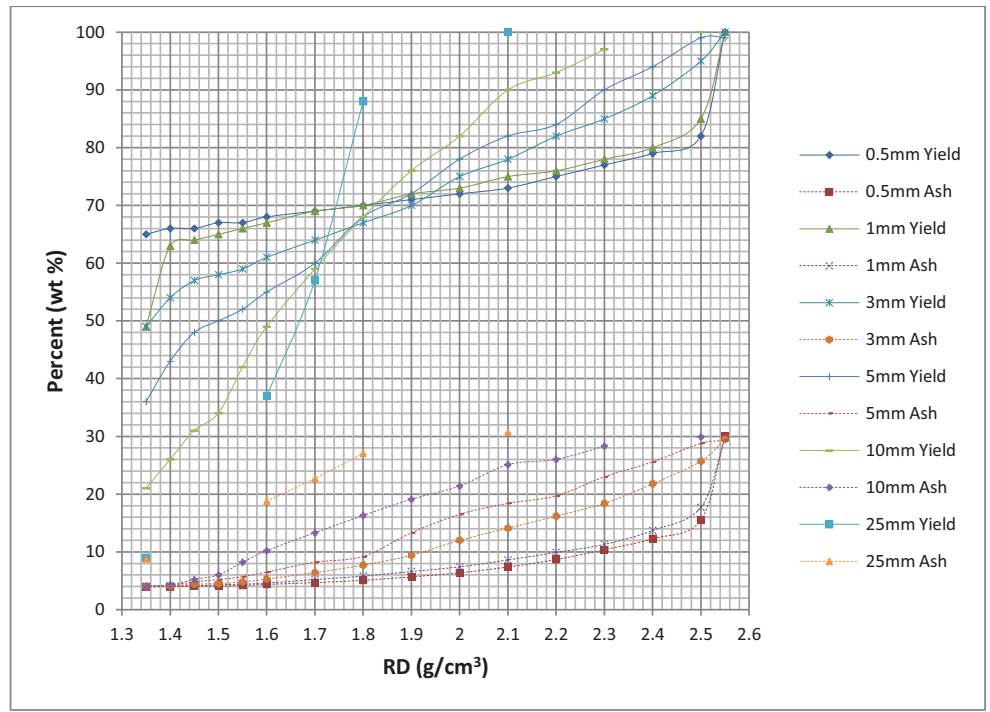

Figure 3. Simulated washability curves for the virtual particle sizes analysed. 
From the results it can be seen that as the virtual particle size increases, the $10 \%$ ash product yield decreases. As the virtual particle size increases, the slope of the simulated washability curves increases, showing that there is an increase in near density material with an increase in virtual particle size.

The yield for a $10 \%$ ash product may be plotted against virtual size (Figure 4). From Figure 4, it can be seen that with an increase in virtual particle size, there is a decrease in $10 \%$ ash product yield.

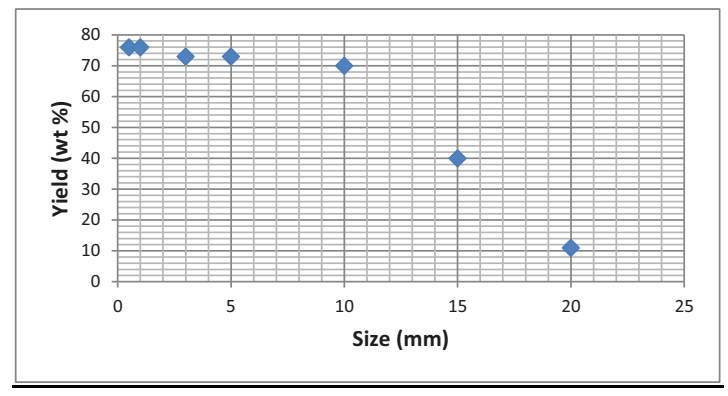

Figure 4. $10 \%$ ash product yield in percentage plotted against virtual particle size in millimetre.

This result clearly shows the risk to $10 \%$ ash product yield with an increase in particle size in the coal sample analysed.

\section{Automation}

Visually logging coal core is a fundamental part of coal resource estimation (Dorland, 2013). An attempt has been made to automatically map out the raw coal components from photographs using image recognition (Van Vuuren et al., 2015). This has been successful where there are clear visual differences between components; however, more work is needed to handle the less clear boundaries. Currently this option is under development.

Also, where there are not clear visual differences between components, $x$-ray scanning may be used to take an image of the coal sample. The coal sample may then be automatically mapped out using software that recognizes the different phases in the coal.

By using software that can estimate volume or area of a block, the component volume or area percentage can be calculated and washability and product liberation determined. Several simulations may then be rapidly obtained that simulate different virtual particle size distributions and their washabilities.

\section{Application}

Traditional physical washability tests performed in a laboratory are costly and time consuming. When automated, this proposed process would be able to provide washability information at a fraction of the cost and time that it takes by traditional laboratory analysis. This process may then be used where traditional washability information cannot be obtained due to cost and time reasons. It is important to note that calibration with real laboratory tests will add accuracy to the simulations. A comparison between the simulation and a laboratory test will be undertaken.

Places where simulated washabilities may be utilised are the following: 
- Exploration boreholes to inform coal resource estimation, laboratory test work and plant design

- Investigate mined material before it enters the plant to inform the plant of what to expect.

\section{Conclusion}

The method described in this paper is non-destructive and several simulations using different specifications for the top size of particles and particle size distributions can be created. Although this method is not proven yet to be $100 \%$ accurate, it rapidly and inexpensively provides relatively accurate washability data. Currently experiments are being performed to validate this method.

This method will compete in the areas where traditional laboratory information is too time consuming and costly to obtain, especially in the control of coal beneficiation plants.

\section{References}

Akinyemi, S.A., Gitari, W.M., Akinlua, A., Petrik, L.F. (2012). Mineralogy and geochemistry of subbituminous coal and its combustion products from Mpumalanga Province, South Africa. http://dx.doi.org/10.5772/50692.

Bunt, J.R., Waanders, F.B. and Schobert, H. (2011). Behaviour of selected major elements during fixed-bed gasification of South African bituminous coal. J.Anal.Appl.Pyrol.,vol. 93, pp. 85 -94. Crelling, J.C. (unknown). Targeting single coal macerals with density gradient centrifugation experiments. Department of Geology, Southern Illinois University.

Dorland, H.C. (2013). Optimising the value of a coal resource by logging its visual metallurgical characteristics. Proceedings of the South African Coal Processing Society Conference, July, Secunda, South Africa.

Dorland, M.I., Campbell, Q.P., Le Roux, M., Erasmus, P., McMillan, K., Dorland, H.C. (2015). Predicting the washability behaviour of coal by numerical simulation of washabilities and product liberation from photographs. Proceedings of the South African Coal Processing Society Conference, 22-24 August, Secunda, South Africa.

Everson, R., Koekemoer, A, Bunt, Neomagus, H, Schwartz, C. (2013). Detailed characterization of South African high mineral matter inertinite-rich coals and density fractions and effect on reaction rates with carbon dioxide: Macerals, microlithotypes, carbominerites and minerals. South African Journal of Chemical Engineering, vol. 18, no. 1, pp 1-16.

Matjie, R.H. and Van Alphen, C. (2008). Mineralogical features of size and density fractions in Sasol coalgasification ash, South Africa and potential by-products. Fuel, vol. 87, pp. 1439-1445.

McMillan, K., Campbell, Q., Le Roux, M., Wagner, N., Dorland, H. (2015). Composition, component size, fracture patterns and product liberation - Washability behaviour of coals from different coalfields of the world. Proceedings of the South African Coal Processing Conference, 22-24 August, Secunda, South Africa.

Van Dyk, J.C., Benson, S.A., Laumb, M.L. and Waanders, F.B. (2009). Coal and coal ash characteristics to understand mineral transformations and slag formation. Fuel, vol. 88, no. 6, p. 10571063.

Van Vuuren, P.A., Dorland, H.C. Le Roux, M., Venter, W.C. Erasmus, P., Dorland, M.I. and Campbell, Q.P. (2015). Using visual texture analysis to classify raw coal components. 22nd International Conference on Systems, Signals and Image Processing, 10-12 September, London UK, pp. 212-215. 